\title{
Electrodialytic remediation of fly ash from co-combustion of wood and straw
}

\author{
Chen, Wan; Jensen, Pernille Erland; Ottosen, Lisbeth M.; Kirkelund, Gunvor Marie
}

Published in:

Electrochimica Acta

Link to article, DOI:

10.1016/j.electacta.2015.04.083

Publication date:

2015

Link back to DTU Orbit

Citation (APA):

Chen, W., Jensen, P. E., Ottosen, L. M., \& Kirkelund, G. M. (2015). Electrodialytic remediation of fly ash from cocombustion of wood and straw. Electrochimica Acta, 181, 208-216.

https://doi.org/10.1016/j.electacta.2015.04.083

\section{General rights}

Copyright and moral rights for the publications made accessible in the public portal are retained by the authors and/or other copyright owners and it is a condition of accessing publications that users recognise and abide by the legal requirements associated with these rights.

- Users may download and print one copy of any publication from the public portal for the purpose of private study or research.

- You may not further distribute the material or use it for any profit-making activity or commercial gain

- You may freely distribute the URL identifying the publication in the public portal

If you believe that this document breaches copyright please contact us providing details, and we will remove access to the work immediately and investigate your claim 


\title{
Electrodialytic remediation of fly ash from co-combustion of wood and straw
}

Wan Chen*, Pernille E. Jensen, Lisbeth M. Ottosen, Gunvor M. Kirkelund

Department of Civil Engineering, Technical University of Denmark, Denmark.

*Corresponding author: e-mail wach@byg.dtu.dk, telephone + 4545251816

Keywords: Electrodialytic remediation; Straw and wood; Fly ash; Heavy metals.

\begin{abstract}
The heavy metal content in fly ash from biomass combustion, such as straw, wood and sludge, often needs reducing before the ash can be used as fertilizer for agricultural land or as a component in the production of construction materials. In this study, fly ash from a boiler fueled with wood chips and straw was treated either by electrodialytic remediation (EDR) directly or by a combination of EDR and pre-wash with distilled water to investigate the possibilities of reducing the heavy metal content and reusing nutrients as fertilizer and bulk material in construction materials. Different experimental set-ups were tested for EDR treatment primarily of $\mathrm{Cd}$ and $\mathrm{Pb}$ as well as of $\mathrm{Cu}$ and $\mathrm{Zn}$. Elemental contents such as K, P and Ni were compared in ash samples before and after treatment. The results showed that pre-washing caused an increase in total concentrations of most heavy metals because the highly soluble fraction, mainly $\mathrm{KCl}$ and $\mathrm{K}_{2} \mathrm{SO}_{4}$, was removed. After EDR treatment, the Cd concentration was reduced to below $2 \mathrm{mg} \mathrm{kg}^{-1}$ in all ash samples with high and stable average removal of above 95\%, no matter how high the initial concentration was. The amount of $\mathrm{Pb}$ removed varied from $12 \%$ to $67 \%$. Even though $\mathrm{Pb}$ was extracted from the ash samples, its concentrations in the treated ash samples were elevated due to the ash dissolution, except in the case of pre-washed ash treated in a two-compartment EDR cell, where the mass of $\mathrm{Pb}$
\end{abstract}


removed was the highest with a final concentration of about $100 \mathrm{mg} \mathrm{kg}^{-1}$. The two-compartment EDR cell probably performed better due to a fast acidification process. In addition, this process was less energy-consuming. However, the fast acidification did in turn affect the leaching property of the treated ash, such as As and Ni, exceeding the limiting concentrations. The EDR/pre-wash-EDR treated ash mainly contained quartz, and the X-ray diffraction (XRD) peaks of $\mathrm{K}$ salts had disappeared. This shows that the potassium fertilizer potential was lost in the treated ashes, but the quartz mineral is beneficial in construction materials, such as ceramics. The $\mathrm{K}$ fertilizer could be recovered from the water after pre-washing and also from the catholyte through chemical operations, including a separation step. 


\section{Introduction}

The European Union's renewable energy target and climate and energy policies have driven the increasing use of renewable energy resources in heat and power production [1]. Field crop residues, such as straw, are one source of agricultural biomass fuels, which are generally cheap in price and abundant in quantity and are, therefore, increasingly being used for energy production. However, pure straw combustion has slagging and fouling problems in boilers because of the high ash content and the high content of chlorine and potassium. Co-combustion of straw with other fuels, such as coal and forest (woody) fuels, can ease the problem by diluting the elements that form straw ash [2]. The main ash-forming elements are: $\mathrm{Al}, \mathrm{Ca}, \mathrm{Fe}, \mathrm{K}, \mathrm{Mg}, \mathrm{Mn}, \mathrm{Na}, \mathrm{P}, \mathrm{S}, \mathrm{Si}$ and $\mathrm{Cl}$ [3]. Straw has a high ash content in the range of $4-7 \%$, whereas wood chips have a relatively low ash content of less than 2\% [4]. By incorporating Ca-rich wood in straw combustion, Ca-rich particles can be deposited in the straw-based K-silicate melt to form silicates and oxides (e.g. CaO) of high melting points, thus changing the elemental composition of the bottom ash and reducing slagging propensity [2]. In Denmark, co-combustion of straw and wood chips has been implemented in some bio-fueled power plants.

The main by-products generated in the co-combustion of wood and straw are bottom and fly ashes. This type of bio-ash usually contains plant nutrients ( $\mathrm{K}$ and $\mathrm{P}$ ) which have value as fertilizers $[5,6]$. The bottom ash can normally be spread on agricultural fields, thus using the fertilizer value directly [7]. In Denmark, the fly ash cannot be used in this way because the heavy metal content (especially Cd [8]) often exceeds the maximum limit value of $5 \mathrm{mg} \mathrm{kg}^{-1} \mathrm{TS}$ (total solid) in the Danish regulation "Bioaskebekendtgørelsen” [9] for use of bio-ash on agricultural land. This study, therefore, focuses on using the resources in fly ash from wood and straw co-combustion. 
EDR (electrodialytic remediation) is a method of removing heavy metals from particulate materials. It was originally developed for remediation of contaminated soils in a stationary, humid state [10], and later developed towards the treatment of fine particulate materials in suspension [11]. In the electric field, mobile ions in the suspension will electromigrate to electrode compartments through anionic or cationic ion exchange membranes, thus achieving a separation of ions from the suspension. The reduction and oxidation of water at the electrodes are the primary reactions occurring in the EDR system [12]. The half reactions are: (1) cathode reaction $2 \mathrm{H}_{2} \mathrm{O}+2 \mathrm{e}^{-} \rightarrow \mathrm{H}_{2} \uparrow+$ $2 \mathrm{OH}^{-}$, and (2) anode reaction $2 \mathrm{H}_{2} \mathrm{O} \rightarrow \mathrm{O}_{2} \uparrow+4 \mathrm{H}^{+}+4 \mathrm{e}^{-}$. Removing Cd from biomass combustion fly ash in a three- or five-compartment EDR setup was reported in [5, 10, 13-15], and EDR turned out to be successful. Not only heavy metals but also other mobile element ions, such as $\mathrm{K}$ and $\mathrm{P}$, are removed from ash suspensions during EDR. Later a two-compartment cell setup was developed for extraction of P from wastewater sludge. In the two-compartment cell, an ash-water suspension is directly acidified from the anode reaction as the anode is placed in the suspension. In this study, the focus is on the separation of nutrient elements and heavy metals for the recovery of the nutrients in an environmentally usable form. If the nutrients recovered can be used on agricultural fields, they will give additional economic value and replace a part of the commercial potash $\mathrm{K}$ fertilizer with a recently reported sale price of about US \$310 per tonne [16]. The reuse of treated ash residue will also give an economic benefit, as disposal of the ashes is expensive in many countries. However, a few studies have reported results related to the possible management of EDR-treated ash residue according to the ash properties [17-19].

In this study, co-combustion fly ash from a boiler fueled with wood chips and straw was treated either by EDR or by a pre-wash/EDR combination to lower the heavy metal content in the ash. We tested a two-compartment EDR cell for the first time to treat such co-combustion ash and compared it with the three-compartment cell regarding heavy metal removal. We investigated the 
influence of the water pre-wash on EDR treatment. This is relevant to industries using water to wash nutrients (mainly K) away from bio-ashes, to offer an alternative technique to handle the ash residues by reducing the heavy metal content. In line with a zero-waste concept, a possible reuse of the detoxified fly ash residue for construction purposes was discussed. Since the fly ash studied contained plant nutrients, how the nutrients could be recovered during EDR or the pre-wash/EDR combination was discussed.

\section{Experimental}

\subsection{Materials}

Two straw/wood co-combustion fly ash (FA) samples from Enstedværket Power Plant (Denmark) were used in this study. The FAs were sampled on different days and were named EFA-1 and EFA-2. After being washed with distilled water in three stages at the total liquid-to-solid (L/S) ratio of $15 \mathrm{l} / \mathrm{kg}$, i.e. $5 \mathrm{l} / \mathrm{kg}$ in each, the fly ash samples were named WEFA-1 and WEFA-2, respectively. The wet ash samples were dried at $105^{\circ} \mathrm{C}$ for $24 \mathrm{~h}$ for further use in the experimental work. The dry mass recovered from the pre-washing step was directly used to calculate the content of soluble compounds.

\subsection{Experiments}

The EDR cells illustrated in Fig. 1 were used in this study. They were different in configuration, i.e. three-compartment (Fig. 1a) and two-compartment (Fig. 1b). In relation to conventional EDR for e.g. water treatment, compartment II in Fig. 1a and compartment I in Fig. 1b were demineralization compartments, where the ash-water suspension was placed. The remaining compartments where the electrodes were placed, were concentration compartments filled with circulating electrolytes (a $0.01 \mathrm{M} \mathrm{NaNO}$ solution with a $\mathrm{pH}$ of 2 adjusted by $\mathrm{HNO}_{3}$ ). In the setup illustrated in Fig. 1b, the anode was directly placed in the ash suspension. The cells were cylindrical 
with an inner diameter of $8 \mathrm{~cm}$ and made from polymethyl methacrylate. The compartment for ash suspension was $10 \mathrm{~cm}$ long and the length of the other compartments was $5 \mathrm{~cm}$.

Table 1 gives the experimental conditions for the EDR experiments conducted. The L/S ratio was set at 7 (350 ml distilled water / 50 g dry ash) according to the experience of Ottosen et al. [10] with respect to straw or wood ash EDR treatment. The constant current density was planned to be the same in all experiments, but in experiment E2 with WEFA-1 the voltage between the two working electrodes reached the maximum output voltage of the power supply on day 1 , so it was decided to decrease the current from $50 \mathrm{~mA}$ to $10 \mathrm{~mA}$ from day 2. The experiments were designed to obtain the effect of stable/low current density (e.g. experiments E2 and E4), different current densities (e.g. experiments E4 and E5), and EDR cells (e.g. experiments E5 and E6) on the treatment. The repeatability of EDR treatment of the raw ash is found in experiments E1 and E3. Details regarding the practical application of EDR in the laboratory experiments are as follows.

- Stirring. A plastic flap mounted on a glass stick was placed inside the ash suspension. The glass stick was fixed into an overhead 'lab egg' stirrer.

- Electrolyte circulation. Pumps were used to keep the electrolytes circulating in electrode compartments. The volume of electrolyte in each compartment was $500 \mathrm{ml}$.

- Power supply. A DC power supply (HP E3612A) maintained the constant output current and monitored the development of voltage between the two working electrodes.

- Measurements and control during the experiment. The conductivity and $\mathrm{pH}$ of the ash suspension and the voltage between the working electrodes were measured once per day. The $\mathrm{pH}$ changes in electrolytes induced by electrode reactions were monitored during the experiment, and the $\mathrm{pH}$ was manually controlled at between 1 and 2 by adding $\mathrm{HNO}_{3}$ and/or $\mathrm{NaOH}$ solutions. Water flux [13] occurred during the experiments, especially in three-compartment cells; this was diminished by adjusting the pumping rate. 


\subsection{Analysis}

Water content was measured as the weight loss during drying at $105^{\circ} \mathrm{C}$ for $24 \mathrm{~h}$ and calculated by ((initial ash mass - dry ash mass)/initial ash mass; \%). The content of organic matter was determined as the weight loss on ignition (LOI) at $550^{\circ} \mathrm{C}$ for $1 \mathrm{~h}$.

The dry ashes were manually grinded prior to the following analyses. Elemental analysis according to Danish Standard DS259 [20]: the concentrations of Cd, Cu, K, P, Pb and Zn were determined after acid digestion, where $1.0 \mathrm{~g}$ of dry ash in $20.0 \mathrm{ml}$ of $1: 1 \mathrm{HNO}_{3}$ was autoclaved at a pressure of $200 \mathrm{kPa}$ at $120^{\circ} \mathrm{C}$ for $30 \mathrm{~min}$. The digested ash solution was vacuum filtered through a $0.45 \mu \mathrm{m}$ filter. Finally, the filtrate was diluted to $100.0 \mathrm{ml}$ for elemental analysis by ICP-OES (Varian 720-ES, Software version: 1.1.0). A series of at least three replicates (number of replicates: N) was made. All concentrations are expressed on a dry mass basis.

The $\mathrm{pH}_{\mathrm{H} 2 \mathrm{O}}$ was measured in distilled water at a $\mathrm{L} / \mathrm{S}$ ratio of 5 . Radiometer analytical $\mathrm{pH}$ electrode was used for $\mathrm{pH}$ determination after $1 \mathrm{~h}$ of agitation of the ash suspension.

The chloride content was extracted by distilled water for $16 \mathrm{~h}$ at a L/S ratio of 5 . After agitation, the ash suspension was filtered through a $0.45 \mu \mathrm{m}$ filter. The concentration of chloride in the filtrate was determined by volumetric titration with standard silver nitrate solution.

The crystalline phases were studied by X-ray diffraction (XRD, $2 \theta \mathrm{Cu} \mathrm{K} \alpha, 40 \mathrm{~mA}, 45 \mathrm{kV}$ ) using a PANalytical Xpert Pro diffractometer.

Leaching tests were conducted referring to the principle in DS/EN 12457-1 [21]. The L/S ratio was 2. The suspension was agitated for $24 \mathrm{~h}$ and then vacuum filtrated through a $0.45 \mu \mathrm{m}$ filter. Concentrated $\mathrm{HNO}_{3}$ was added to the filtrate for the purpose of preserving the sample before the determination of elemental concentrations by ICP-OES.

\section{Results}




\subsection{Ash characterization}

EFA-1 and EFA-2 were very similar in their general properties such as $\mathrm{pH}$, conductivity, water content, LOI and chloride concentration (Table 2). The slight differences could be explained by the variation in straw/wood ash fractions on the dates of ash sampling. Straw ash normally has a slightly acidic to neutral $\mathrm{pH}$ and high content of chloride and soluble salts, while wood ash is alkaline due to the presence of alkaline oxides (e.g. $\mathrm{CaO}$ ) and has low dissolution and chloride content [22]. The EFAs studied inherited the most characteristics of straw ash, because straw was the dominating fuel in the combustion process. The average consumption of straw in the power plant takes about $80 \%$ of the total consumption of straw and wood chips [23]. The water solubilities of EFAs were high at $83 \%$ and $75 \%$, respectively. The high content of $\mathrm{K}$ in the wash water together with the remarkable decrease in chloride concentration in the ash from about $23 \%$ to $0.1 \%$ and the XRD result of EFA-1 (Table 2) suggested that the most easily soluble salts washed out were $\mathrm{KCl}$ and $\mathrm{K}_{2} \mathrm{SO}_{4}$. The peaks of $\mathrm{K}$ and $\mathrm{Cl}$ disappeared from the XRD pattern after washing. Washing caused an increase in $\mathrm{pH}$ of WEFAs to above 9.4. The species of $\mathrm{CaCO}_{3}$ and $\mathrm{CaSO}_{4}$ detected in the pre-washed EFA can explain the increase in $\mathrm{pH}$.

Compared with the limiting values for bio-ash as fertilizer regulated in [9], i.e. maximum 5 mgCd kg ${ }^{-1}$ TS, 100 mgCr kg-1 TS, 60 mgNi kg-1 TS and 120 mgPb kg$^{-1} \mathrm{TS}$, Cd was the main problematic heavy metal in EFAs $\left(9 \mathrm{mg} \mathrm{kg}^{-1}\right.$ ) prohibiting their spread on agricultural land (Table 2). The heavy metal contents in WEFAs were all higher than in the original EFAs, as were Ca and P but not K, which supports the proposition that a large proportion of $\mathrm{K}$ in EFAs was water-soluble. The water solubility of $\mathrm{P}$ might be low, and the enrichment of $\mathrm{Ca}$ is believed to be due to the precipitation of $\mathrm{Ca}$ on the ash particles in the form of $\mathrm{CaSO}_{4}$ and $\mathrm{CaCO}_{3}$ (Table 2) during washing. Besides $\mathrm{Cd}$, the concentration of $\mathrm{Pb}$ in WEFAs was elevated to a problematic level, i.e. higher than $135 \mathrm{mg} \mathrm{kg}^{-1} \mathrm{TS}$. Therefore, the target elements in our EDR experiments were the problematic Cd 
and $\mathrm{Pb}$, but $\mathrm{Cu}$ and $\mathrm{Zn}$ were also included since $\mathrm{Cu}$ can be problematic in wood ash and $\mathrm{Zn}$ had relatively higher concentrations in the samples studied.

\subsection{EDR experiments}

\subsubsection{Mass balances}

Mass balance (mass out $_{\text {mass }}$, \%) shows the relationship between the total mass output of a contaminating element from the whole EDR system (compartments, electrodes and membranes) after treatment and its initial mass input from the ash. The values given in Table 3 are not exactly $100 \%$, mainly due to the unhomogeneous nature of the ash samples. The mass balances of the four target elements are acceptable referring to [24], and varied between $78 \%$ and $138 \%$ with an average of $108 \%$.

\subsubsection{Voltage, $\mathrm{pH}$ and conductivity}

Significant changes in $\mathrm{pH}$ and conductivity of the ash suspensions, and in voltage between the working electrodes were seen within the first 14 days of EDR treatment, as shown in Fig. 2.

Low and stable voltage (2.8-5.3 V) was seen throughout the experiments E1 and E3 (Fig. 2A) due to the high content of easily soluble salts resulting in high conductivity of the raw ash suspensions (Fig. 2C). During these two experiments, the conductivity of the suspensions decreased as ions were electromigrating into the electrode compartments, but the conductivity never limited the flow of current. The conductivity decreased faster during the first week of experiment than after. This can be explained by the acidification of ash suspension (Fig. 2B) where the $\mathrm{H}^{+}$ions and subsequent ash dissolution added to the overall conductivity.

The voltage in experiment E2 with pre-washed ash, on the other hand, increased to the maximum output of the power supply during the first day when the same current, i.e. $50 \mathrm{~mA}$, was 
applied. The conductivity of such a pre-washed ash suspension was too low to maintain this high current after washing the soluble parts out. The current was changed to $10 \mathrm{~mA}$ so as to maintain a constant applied current. This was an appropriate current for treatment of pre-washed ash as the voltage varied no more than $\pm 2 \mathrm{~V}$ from the average value of $4 \mathrm{~V}$ as seen in experiment $\mathrm{E} 4$. After day 14, the voltage in experiments E2 and E4 showed very weak fluctuations around $2.5 \mathrm{~V}$, and the $\mathrm{pH}$ of their ash suspensions kept decreasing till a steady state was reached at $\mathrm{pH}$ around 1.90 , but the conductivity slowly increased to $30 \mathrm{mS} \mathrm{cm}^{-1}$ in the end. Unlike E4, experiment E5 showed considerable variation in voltage from $9 \mathrm{~V}$ to $116 \mathrm{~V}$ within 10 days. The current applied, $40 \mathrm{~mA}$, seemed too high for treatment of the low conductive pre-washed ash in a three-compartment EDR cell compared with that in experiment E4. The dramatic increase in voltage in experiment E5 within two days was probably due to the extensive ion-concentration polarization at the membrane surfaces and, very important, the high resistance of the ash suspension. Experiment E6 had a different voltage development pattern from experiment E5 despite the same current applied. Instead of initially increasing and then decreasing, the voltage kept decreasing from about $16 \mathrm{~V}$ to $3 \mathrm{~V}$. The pre-washed ash suspension had very low initial conductivity, but the fast acidification from the anode reaction in experiment E6 caused an increase in conductivity throughout the experiment. The $\mathrm{pH}$ decreased accordingly. The comparison between experiments E5 and E6 shows that a faster decrease in $\mathrm{pH}$ and increase in conductivity in a two-compartment cell can be achieved than in a three-compartment cell at the same current density.

\subsubsection{Changes in ash composition during treatment}

In general, the concentrations of selected heavy metals in the ash samples decreased after EDR treatment except $\mathrm{Ni}$ in experiments $\mathrm{E} 1$ and $\mathrm{E} 3$, and $\mathrm{Cr}$ and $\mathrm{Pb}$ in experiments $\mathrm{E} 1$ to $\mathrm{E} 5$, by comparing the initial (Table 2) with the final (Table 4) concentrations. Both experiments E1 and E3 were used for treatment of EFAs, so the lower content of $\mathrm{Ni}$ in raw ash compared with the amount 
of ash dissolved during EDR treatment explained the increase in Ni. No increase in $\mathrm{Cr}$ and $\mathrm{Pb}$ concentrations was seen in experiment E6, although it was seen in the other experiments, which suggested that the two-compartment cell generally gave a better removal of heavy metals than the three-compartment cell. Compared with experiment $\mathrm{E} 5$, the enhanced removal of $\mathrm{Pb}$ and $\mathrm{Cr}$ in experiment E6 is probably associated with the faster $\mathrm{pH}$ decrease in the two-compartment cell (Fig. 2B). All the selected elements were within the limiting concentrations for spreading on agricultural land after treatment in experiment E6.

An XRD analysis was made on the ash treated in experiment E1, and here the main crystalline phase detected was quartz, which is normally acid-insoluble (except in HF). This could support the hypothesis that $\mathrm{SiO}_{2}$ is the main crystalline residue after EDR treatment.

Leaching properties of the ashes treated in experiments E5 and E6 were given in Table 5. Compared with the values obtained from EFA-2, the leachability of all the listed elements (except Ni) was reduced after washing and EDR treatment.

\subsubsection{Elemental distribution}

Fig. 3 shows the distributions of $\mathrm{Cd}, \mathrm{Cu}, \mathrm{Zn}, \mathrm{Pb}, \mathrm{P}$ and $\mathrm{K}$ in the whole EDR system. In general, the cationic species, such as $\mathrm{Cd}, \mathrm{Cu}, \mathrm{Pb}, \mathrm{Zn}$ and $\mathrm{K}$, were primarily transported to the cathode end, and the anionic species, such as $\mathrm{PO}_{4}{ }^{3-}$, primarily migrated to the anode end. The outcome of experiment E5 was the best with respect to a good elemental distribution and separation as the content of heavy metals in filtrate from the ash suspension was very low. The filtrate and anolyte with low heavy metal content may be used as a source for P fertilizer. It is likely that the properties of pre-washed ash, such as less solubility and alkaline $\mathrm{pH}$, were related to the special performance of experiment E5. The $\mathrm{CaCO}_{3}$ content in the pre-washed ash implied higher buffering capacity to the acidification process, and washing may convert heavy metal compounds into less reactive forms 
[25], resulting in almost unchanged conductivity which may suggest that there was a balance between the release and removal of mobile ions.

\subsubsection{Energy consumption}

The equation, $\mathrm{E}=\mathcal{N} \mathrm{VIt} / \mathrm{W}$ [26], was used to estimate the energy consumptions in the EDR experiments, where $\mathrm{E}$ is the power consumption per gram ash ( $\mathrm{Wh}^{-1}$ ); $\mathrm{V}$, voltage between working electrodes (V); I, current (A); t, duration (h); W, the mass of ash (g). Comparing experiment E5 with E6, a lower energy consumption (Table 4) was seen in the latter due to the rapid increase in conductivity (Fig. 2C). At the same time, the concentrations of heavy metals obtained in E6 using a two-compartment cell were the lowest, so the energy efficiency was the highest in this setup.

\section{Discussion}

\subsection{Overall removal}

The operational parameters in EDR (current density, L/S and duration of treatment) affect the outcome of remediation, and a delicate balance must be maintained to obtain the most efficient treatment [11]. In the present study, extending the duration from 10 to 14 days did not have a great impact on the removal of Cd from raw ashes in the three-compartment EDR cell (experiments E1 and E3), so the remediation could be conducted in less than 10 days under the same conditions. The duration between 10 and 14 days, on the other hand, affected the removal of $\mathrm{Cu}, \mathrm{Pb}$ and $\mathrm{Zn}$, and the results (Table 4) imply that a longer duration can reduce the content of $\mathrm{Pb}$ and $\mathrm{Cu}$; this has also been seen in EDR treatment of contaminated soils $[27,28]$. The goal of remediation, therefore, determines the duration. Where Cd is the only target element, the duration is relatively short, but if $\mathrm{Pb}$ is a target element as well, the duration must be significantly longer. When comparing the overall results, it can be found that EDR treatment of unwashed ash gave better results than the 
treatment of pre-washed ash in the three-compartment cell in terms of heavy metal content in the ash after treatment and energy consumption of the treatment.

EDR treatment of straw and/or wood ashes within 14 days has shown great potential. Previous experiments were conducted in the three/five-compartment cell on straw or wood ash separately [5, $10,14,22]$. Ottosen et al. [10] conducted EDR experiments for 14 days at the current density of 0.8 $\mathrm{mA} \mathrm{cm}^{-2}$ (corresponding to approximately $40 \mathrm{~mA}$ ), and achieved removal of Cd of $75 \%$ and $45 \%$ from straw ash and wood ash, respectively. The corresponding $\mathrm{Pb}$ removals were $66 \%$ and $19 \%$. Kirkelund et al. [5] treated a straw fly ash and a pre-washed straw ash with high initial Cd concentrations of 19 and $64 \mathrm{mg} \mathrm{kg}^{-1} \mathrm{TS}$, respectively. They achieved a Cd concentration below $2 \mathrm{mg} \mathrm{kg}^{-1} \mathrm{TS}$ in the raw straw fly ash after treatment at a L/S ratio of 7 and a current of $40 \mathrm{~mA}$ (equivalent to the current density of $0.8 \mathrm{~mA} \mathrm{~cm}^{-2}$ ) for 14 days. At the same current density and duration, a decrease in Cd concentration in the pre-washed ash was gained of between 3.5 and 2 mg $\mathrm{kg}^{-1} \mathrm{TS}$ when the L/S ratio varied from 7 to 13 .

In summary, EDR can be used not only as a method for direct fly ash treatment, but also as a post-treatment method after pre-treatment by washing. This is consistent with the finding in [24]. Our study also suggests that the sudden increase in current density as a result of very low conductivity of the ash suspension is not preferable in the extraction of some metals even when the same charges passed. For example, the removal efficiencies of $\mathrm{Pb}$ were $18 \%$ in experiment $\mathrm{E} 2$ where the voltage reached high levels, and 25\% in experiment E4 with low initial current and stable voltage throughout the experiment (Table 4). Thus it is advisable to determine the optimal current density at laboratory scale before scaling up the process. The type of EDR cells should be selected according to the aim of treatment and properties of the materials.

\subsection{Removal of $\mathrm{Cd}, \mathrm{Pb}, \mathrm{Cu}$ and $\mathrm{Zn}$}


Calculating the removal efficiency of $\mathrm{Cd}$ (as the total mass difference in the ash before and after treatment divided by the total initial mass of Cd), a quite stable and high level of efficiency in the removal of Cd was seen under all the experimental conditions (Table 4). The removal efficiencies are in the order: E1=E3=E6>E4=E2>E5. Compared with the removal efficiencies reported in [10], the values in our study were high and more than $94 \%$ of Cd was removed. The final Cd concentration of below $2 \mathrm{mg} \mathrm{kg}^{-1}$ was obtained in both this study and [10]. The majority of the Cd ions electromigrated to the cathode compartment (Fig. 3), but they were also found in the anode compartment in four of the experiments, i.e. E1-E4 (maximum about 30\%). Removal of Cd ion towards the anode was described in [10] and [14] in detail. It can be concluded that many different Cd complexes can form when ash is suspended, and they can be positive $\left(\mathrm{Cd}^{2+}\right.$ and $\left.\mathrm{CdCl}^{+}\right)$, negative $\left(\mathrm{CdCl}^{3-}\right.$ and $\left.\mathrm{CdCl}^{4-}\right)$ or neutral $\left(\mathrm{CdCl}_{2}\right)$. Hansen et al. [14] pointed out that Cd was mainly removed as $\mathrm{CdCl}_{4}{ }^{2-}$ at the beginning of remediation, and with the decrease in $\mathrm{Cl}$ content and $\mathrm{pH}, \mathrm{Cd}$ is present as $\mathrm{Cd}^{2+}$. As the percentages of Cd in anolyte were the highest in experiments E1 and E3, negatively charged chloride complexes in the raw ashes may be an explanation. In experiments E2 and E4, other anionic Cd complexes must be prevalent. Experiment E5 showed another pattern, where about $95 \%$ of Cd was found at the cathode end and about $5 \%$ was left in the ash. The ash used in this experiment was water-washed, which resulted in a very low chloride content $(0.1 \%$, Table 2) in the ash. Thus the formation of negatively charged $\mathrm{Cd}-\mathrm{Cl}$ complexes will not occur to an extent of any importance to EDR. The major difference between experiment E5 and the other two experiments E2 and E4 for treatment of pre-washed ash is a higher current applied in E5. The pattern of separation of Cd from the ash in E5 shows that the formation of negatively charged Cd complexes is less at higher current, which again may imply that the removal rate is faster than the kinetics for such complexes to form. Thus optimization of the current is crucial to the outcome of treatment also from this point of view. 
$\mathrm{Pb}$ can be transported to both the cathode and the anode compartment (Fig. 3). The same behaviour was shown by Ottosen et al. [10] where chloride complexes were proposed to explain the removal of $\mathrm{Pb}$ to the anode end; this may also explain the distribution pattern of $\mathrm{Pb}$ in experiment E5. In [10], the removal efficiencies of $\mathrm{Pb}$ were $33 \%$ and $66 \%$ from the wood ash and straw ash, respectively. In our study, the removal efficiency varied from $12 \%$ to $67 \%$. The low removal efficiency does not, however, reflect the small amount of mass removed (Table 4). $\mathrm{Pb}$ removal efficiencies (highest percentage) are in the order of E1>E3>E6>E4>E2>E5, and the mass of $\mathrm{Pb}$ removed is in the order E6>E4>E2>E1>E3>E5. The removal efficiency and mass removed were in the same pattern for EFAs (E1>E3) and WEFAs (E6>E4>E2>E5). The low Pb concentration in raw ashes explained the higher removal efficiency even when a lower mass removed. The twocompartment cell setup used in experiment E6 had a great advantage in treatment of WEFAs, even at the same current density as in experiment E5 but with the lowest charge passed. Stable current improved the removal efficiency of $\mathrm{Pb}$ from WEFAs. A high current density seemed not to be competitive (E5 against E4) for the removal of $\mathrm{Pb}$ from WEFAs in three-compartment cell, as exemplified in experiment E5 having the lowest removal in both efficiency and mass. It could be concluded that a longer duration of treatment, faster decrease in $\mathrm{pH}$ and stable current favour efficient $\mathrm{Pb}$ removal, and the properties of the material also influence the outcome of EDR treatment.

Unlike $\mathrm{Cd}$ and $\mathrm{Pb}$, which were problematic in the ashes studied, there are no limiting values for $\mathrm{Cu}$ and $\mathrm{Zn}$ in [9] for bio-ash spread as fertilizer, but their concentrations in the ashes before treatment were relatively high and their concentrations were also affected by EDR treatment. During EDR the removal was sufficient for the concentrations not to increase as a result of ash dissolution. The results showed that the contents of $\mathrm{Cu}$ and $\mathrm{Zn}$ in the treated ashes were lower than 
$75 \mathrm{mg} \mathrm{kg}^{-1} \mathrm{TS}$ and $300 \mathrm{mg} \mathrm{kg}^{-1} \mathrm{TS}$, respectively, with average removal efficiencies of $81 \%$ and 97\%, respectively.

\subsection{Washing and EDR}

EDR can be used for post-treatment of water-washed ashes. By including EDR, heavy metals can be removed, valuable metals or nutrients may be further recovered, and the residue after remediation may be reused, therefore reducing the amount of waste for landfill and avoiding taxrelated disposal. Challenges are faced in the application of the pre-wash/EDR combination, including how to deal with the wash water.

Pre-wash results in ash wash water. The elemental contents in the wash water after washing EFA-2 were measured. The analyses showed that the water contained about $26 \mathrm{~g} \mathrm{dm}^{-3}$ of $\mathrm{K}, 363 \mathrm{mg}$ $\mathrm{dm}^{-3}$ of P, $195 \mathrm{mg} \mathrm{dm}^{-3}$ of Ca, $0.4 \mathrm{mg} \mathrm{dm}^{-3}$ of Cd, $0.1 \mathrm{mg} \mathrm{dm}^{-3}$ of $\mathrm{Cu}, 0.03 \mathrm{mg} \mathrm{dm}^{-3}$ of $\mathrm{Pb}$ and $3 \mathrm{mg}$ $\mathrm{dm}^{-3}$ of Zn. The pre-washing greatly transferred the easily soluble contents into water, mainly $\mathrm{K}$, and the K-rich water could be used as $\mathrm{K}$ fertilizer. But as irrigation water for agriculture, care should be taken of the heavy metal content in the wash water, because heavy metals can accumulate in soils, be taken up by crops and, therefore, affect crop growth. The recommended maximum concentrations of $\mathrm{Cd}, \mathrm{Cu}, \mathrm{Pb}$ and $\mathrm{Zn}$ in irrigation water are $0.01,0.20,5.0$ and $2.0 \mathrm{mg} \mathrm{dm}^{-3}$, respectively, when a water application rate is not more than $10000 \mathrm{~m}^{3}$ per hectare per year [29]. They can be toxic to crops at different levels. For example, in nutrient solutions $0.1 \mathrm{mg} \mathrm{dm}^{-3} \mathrm{Cd}$ is toxic to beans, beets and turnips, and $0.1 \sim 1.0 \mathrm{mg} \mathrm{dm}^{-3} \mathrm{Cu}$ can be harmful to many plants [29]. Cd concentration in our wash water was 40 times higher than the recommended concentration. Zn also exceeded the recommended value. As a result, the washing process has to be optimized in the operational parameters to meet the requirements for irrigation water, for example the L/S ratio, or a separation step is needed to remove the heavy metals, especially Cd, from the wash water. 
To optimize the washing process, the experience from DongEnergy, which has a pilot plant to produce liquid $\mathrm{K}$ fertilizer from straw fly ash, can be used for reference. In their process, the L/S ratio is controlled to maintain a high $\mathrm{K}$ content in the water in order to transform it into liquid $\mathrm{K}$ fertilizer, and the $\mathrm{pH}$ of the water is adjusted to between 9 and 10 by adding $\mathrm{NaOH}$ or $\mathrm{HCl}$ to minimize the heavy metal content [30]. Electrodialytic treatment could be an option for the removal of heavy metals from the wash water.

EDR treatment results in electrolytes containing heavy metals and some plant nutrients as well as filtrate from ash suspension and the treated ash. The separation of heavy metals and nutrients from electrolytes could be achieved by chemical precipitation, and filtrate could have fertilizer potential (for example, the $\mathrm{P}$ concentrated filtrate in experiment E6), even though the $\mathrm{P}$ concentration was reduced in the treated ash. Where the recovery from these solutions is not feasible, reuse of the liquids in the EDR process is the preferred option.

\subsection{Possible use of treated ash}

Both this and the previous study showed successful Cd removal by EDR from pre-washed bioashes. The selection of EDR cell composition and operational conditions need to be optimized during laboratory studies relating to both the economic and technical aspects. For example, lower energy consumption and shorter treatment time may be achieved using two-compartment EDR cell, but leaching of some heavy metals may pose problems (Table 5). For example, the fast acidification in experiment E6 affected the leaching property of the treated ash, where As, Se and Ni exceeded the limiting concentrations (Table 5) for possible reuse of waste materials in the construction industry [31]. Ni needed attention when the ashes were treated in three-compartment cell. The leaching of $\mathrm{Ni}$ and As was higher from the ash in experiment E6 than in experiment E5, probably because the lower $\mathrm{pH}$ resulted in a chemical environment favouring formation of soluble $\mathrm{Ni}$ and $\mathrm{As}$ 
during an accelerated dissolution of ash. The soluble Ni and As present in filtrate attached to the particle surface, leached out again into water. The fractions of $\mathrm{Ni}$ and As found in filtrate and treated ash in experiments E5 and E6 could support the explanation: (filtrate/ash) $\mathrm{E}_{6}$ : (filtrate/ash) E5 $_{5}$ $=(33 \% / 39 \%):(1 \% / 60 \%)$ for $\mathrm{Ni}$ with mass balances of 148\% and 95\% in E6 and E5, respectively; (filtrate/ash) $)_{\mathrm{E} 6}$ : (filtrate/ash $)_{\mathrm{E} 5}=(25 \% / 14 \%):(1 \% / 8 \%)$ for As with mass balances of $86 \%$ and $101 \%$ in E6 and E5, respectively. However, experiments should be done to get more data to optimize the treatment in respect to leaching properties of toxic elements.

This study showed that the EDR-treated ashes had low fertilizer value, especially due to the dramatic reduction in $\mathrm{K}$ content according to the elemental measurement and the disappearance of $\mathrm{KCl}$ peaks in the XRD pattern. Only a few works can be found on the nutrient content of EDRtreated bio-ashes. Lima et al. [7] discussed whether the ash, if spread on agricultural land after treatment, could mainly have qualities for soil amendment due to the acidic $\mathrm{pH}$ and low fertilizer value. A more attractive possibility of reuse is in the production of construction materials. Biomass fly ash has been studied quite extensively as a secondary construction raw material, such as partly replacing cement in the production of concrete/mortar [22, 32] or clay in brick production [33, 34]. The advantages of this kind of reuse are reducing $\mathrm{CO}_{2}$ emission, saving natural materials, reducing energy consumption in building material production and decreasing need for landfilling.

When bio-ashes are used for part substitution of clay in bricks, a problem may occur with the soluble salts causing efflorescence in fired bricks. Ash washing and EDR have an advantage in this sense in the removal of soluble salts such as chlorides and sulfates. Compared with the limiting elemental concentrations for ashes used in construction materials in category 1 [31] (maximum 20 mgAs kg-1 TS, 0.5 mgCd kg-1 TS, 500 mgCr kg-1 TS, 500 mgCu kg ${ }^{-1}$ TS, 30 mgNi kg-1 $^{-1}$, 40 mgPb kg ${ }^{-1}$ TS and 500 mgZn kg-1 TS), the raw ashes exceeded in Cd and $\mathrm{Zn}$, the pre-washed ashes exceeded in $\mathrm{As}, \mathrm{Cd}, \mathrm{Pb}$ and $\mathrm{Zn}$, and all of the EDR-treated ashes exceeded in $\mathrm{Cd}$ and $\mathrm{Pb}$. The 
preliminary study by Chen et al. [17] about the application of EDR-treated bio-ash in clay brick production showed that it is promising to use the EDR-treated straw and wood co-combustion fly ash as a clay substitute, since the ash contained mainly $\mathrm{SiO}_{2}$. In addition, the bricks made from municipal solid waste incineration residues, which are more toxic than the co-combustion fly ash, had low leaching with regards to $\mathrm{Cd}$ and $\mathrm{Pb}$. The metals $\mathrm{Cd}$ and $\mathrm{Pb}$ probably cause a limited problem, but a comprehensive study of the application of the ashes studied is needed in order to assess their use in the brick sintering process.

\section{Conclusions}

The problem with the Cd concentration exceeding limiting values in fly ash from cocombustion of straw and wood chips can be solved by EDR, as a concentration lower than $2 \mathrm{mg} \mathrm{kg}^{-}$

${ }^{1}$ TS can be obtained. The method is efficient in extracting other heavy metals as well, such as $\mathrm{Pb}$, $\mathrm{Cu}$, and $\mathrm{Zn}$. A water-washing process stabilizes the ash properties by removing easily soluble salts, mainly potassium and chloride, where chlorides could form complexes with heavy metals such as $\mathrm{Cd}, \mathrm{Pb}$ and $\mathrm{Ni}$ hindering good separation during EDR. Placing the anode directly in the ash suspension (two-compartment cell) gave a faster acidification process, facilitating $\mathrm{Cd}$ and $\mathrm{Pb}$ extraction from the pre-washed ash with a lower energy consumption than in the traditional threecompartment cell, but the leaching-related problem was found in the ash after treatment.

$\mathrm{K}$ and $\mathrm{P}$ are two nutrient elements in the ash that can be used as fertilizer. $\mathrm{K}$ can be recovered by water-washing the raw ash since most of $\mathrm{K}$ is water-soluble, and the heavy metal content in the liquid fertilizer could be controlled by adjusting the liquid-to-solid ratio and $\mathrm{pH}$ of the solution. $\mathrm{K}$ was found primarily located at the cathode end of the EDR system, co-existing with other heavy metal cations. A feasible way to separate $\mathrm{K}$ could be by chemical precipitation of these heavy metals at alkaline $\mathrm{pH}$. The $\mathrm{P}$ concentration was lower than $\mathrm{K}$ in the ashes studied, and $\mathrm{P}$ is primarily 
transported to the anode compartment. In the two-compartment cell P was well separated from the mobilized heavy metals, as P remained in the filtrate from the ash suspension and the heavy metals were removed into catholyte.

The XRD analysis showed that the ashes studied underwent dramatic changes in the main mineral compositions: from $\mathrm{KCl}$ and $\mathrm{K}_{2} \mathrm{SO}_{4}$ in the raw ashes, to quartz and calcium carbonates and sulfates after water-washing, finally to mainly quartz in the ashes after EDR treatment. These transformations in ash mineralogy together with the elemental analyses ( $\mathrm{K}$ removal rate $\geq 75 \%$ and highest 99\% when treating the raw ashes; P removal rate $>85 \%$ ) further indicate that the fertilizer value of the treated ashes has decreased greatly. Other applications, such as in ceramics or in construction materials where quartz is normally involved, could possibly be an option for reuse of the treated ashes.

\section{Acknowledgments}

The reported work was financially supported by the Department of Civil Engineering at the Technical University of Denmark.

[1] P. McKendry, Energy production from biomass (part 1): overview of biomass, Bioresource technology, 83 (2002) 37-46.

[2] D. Nordgren, H. Hedman, N. Padban, D. Boström, M. Öhman, Ash transformations in pulverised fuel cocombustion of straw and woody biomass, Fuel processing technology, 105 (2013) 52-58.

[3] J. Werkelin, B.-J. Skrifvars, M. Zevenhoven, B. Holmbom, M. Hupa, Chemical forms of ash-forming elements in woody biomass fuels, Fuel, 89 (2010) 481-493.

[4] J. Koppejan, S. Van Loo, The handbook of biomass combustion and co-firing, Routledge2012.

[5] G.M. Kirkelund, A.J. Damoe, L.M. Ottosen, Electrodialytic removal of Cd from biomass combustion fly ash suspensions, Journal of Hazardous Materials, 250-251 (2013) 212-219.

[6] M.-L. Sander, O. Andrén, Ash from cereal and rape straw used for heat production: liming effect and contents of plant nutrients and heavy metals, Water, air, and soil pollution, 93 (1997) 93-108.

[7] A.T. Lima, L.M. Ottosen, A.B. Ribeiro, Electroremediation of straw and co-combustion ash under acidic conditions, Journal of hazardous materials, 161 (2009) 1003-1009. 
[8] L.M. Ottosen, I.V. Kristensen, A.J. Pedersen, H.K. Hansen, A. Villumsem, A.B. Ribeiro, Electrodialytic removal of heavy metals from different solid waste products, SEPARATION SCIENCE AND TECHNOLOGY, 38 (2003) 1269-1289.

[9] BEK nr 818, Bekendtgørelse om anvendelse af bioaske til jordbrugsformål (Bioaskebekendtgørelsen), Miljøministeriet, (2008 (In Danish)).

[10] L.M. Ottosen, A.J. Pedersen, H.K. Hansen, A.B. Ribeiro, Screening the possibility for removing cadmium and other heavy metals from wastewater sludge and bio-ashes by an electrodialytic method, electrochimica acta, 52 (2007) 3420-3426.

[11] P.E. Jensen, L.M. Ottosen, B. Allard, Electrodialytic versus acid extraction of heavy metals from soil washing residue, Electrochimica Acta, 86 (2012) 115-123.

[12] A. Ribeiro, J. Rodríguez-Maroto, E. Mateus, E. Velizarova, L.M. Ottosen, Modeling of electrodialytic and dialytic removal of $\mathrm{Cr}$, Cu and As from CCA-treated wood chips, Chemosphere, 66 (2007) 1716-1726.

[13] A.T. Lima, L.M. Ottosen, A.B. Ribeiro, H.K. Hansen, Electrodialytic removal of Cd from straw ash in a pilot plant, Journal of Environmental Science and Health Part A, 43 (2008) 844-851.

[14] H.K. Hansen, L.M. Ottosen, A. Villumsen, Electrodialytic removal of cadmium from straw combustion fly ash, Journal of Chemical Technology and Biotechnology, 79 (2004) 789-794.

[15] A.J. Pedersen, Characterization and electrodialytic treatment of wood combustion fly ash for the removal of cadmium, Biomass and Bioenergy, 25 (2003) 447-458.

[16] Scotiabank Commodity Price Index, www.scotiabank.com, September 29, 2014.

[17] W. Chen, L.M. Ottosen, P.E. Jensen, G.M. Kirkelund, J.W. Schmidt, A comparative study on

electrodialytically treated bio-ash and MSWI APC-residue for use in bricks, 5th International Conference on Engineering for Waste and Biomass Valorisation, Mines d'Albi, Rio de Janeiro, Brazil, 2014.

[18] G.M. Kirkelund, M.R. Geiker, P.E. Jensen, Electrodialytically treated MSWI APC residue as substitute for cement in mortar, Nordic Concrete Research, (2014) 1-16.

[19] G.M. Kirkelund, M.R. Geiker, P.E. Jensen, Feasability test of electrodialytically upgraded MSWI APC residue utilization in mortar, Proceedings Papers: 3rd International Conference on Engineering for Waste and Biomass Valorisation, (2010).

[20] DS 259, Determination of metals in water, sludge and sediments - General guidelines for determination by atomic absorption spectrophotometry in flame, (2003).

[21] DS/EN 12457-1, Characterisation of waste - Leaching - Compliance test for leaching of granular waste materials and sludges, part 1: One stage batch test at a liquid to solid ratio of $2 \mathrm{l} / \mathrm{kg}$ for materials with high solid content and with particle size below $4 \mathrm{~mm}$ (without or with size reduction), (2002).

[22] A. Lima, L.M. Ottosen, A.B. Ribeiro, Assessing fly ash treatment: remediation and stabilization of heavy metals, Journal of environmental management, 95 (2012) S110-S115.

[23] J. Staal, DONG Energy Power plans and experience in Biomass, available at

https://www.essent.eu/content/Images/90684_04_DONG\%20plans\%20in\%20biomass_Jesper\%20Staal.pdf.

[24] P.E. Jensen, L.M. Ottosen, B. Allard, Electrodialytic versus acid extraction of heavy metals from soil washing residue, Electrochimica Acta, 86 (2012).

[25] T. Mangialardi, Disposal of MSWI fly ash through a combined washing-immobilisation process, JOURNAL OF HAZARDOUS MATERIALS, 98 (2003) 225-240.

[26] T.R. Sun, L.M. Ottosen, P.E. Jensen, G.M. Kirkelund, Electrodialytic remediation of suspended soilComparison of two different soil fractions, Journal of hazardous materials, 203 (2012) 229-235.

[27] L.M. Ottosen, P.E. Jensen, H.K. Hansen, A.B. Ribeiro, B. Allard, Electrodialytic Remediation of Soil Slurry-Removal of Cu, Cr, and As, Separation Science and Technology, 44 (2009) 2245-2268.

[28] P.E. Jensen, L.M. Ottosen, C. Ferreira, A. Villumsen, Kinetics of electrodialytic extraction of Pb and soil cations from a slurry of contaminated soil fines, JOURNAL OF HAZARDOUS MATERIALS, 138 (2006) 493-499. [29] R.S. Ayers, D.W. Westcot, Water quality for agriculture, FAO Rome1985.

[30] L. Nikolaisen, J. Hinge, I. Christensen, J. Dahl, P. Arendt Jensen, T. Søndergaard Birkmose, B. Sander, O. Kristensen, R.E. Danish Technological Inst, Utilization of ash fractions from alternative biofuels used in power plants, 2008. 
[31] BEK nr 1662, Danish Ministry of the Environment, Bekendtgørelse om anvendelse af restprodukter og jord til bygge- og anlægsarbejder og om anvendelse af sorteret, uforurenet bygge- og anlægsaffald, (21/12/2010) (in Danish)

[32] S. Wang, L. Baxter, Fly ash and concrete, Concrete Producer, Concrete Prod, 24 (2006) 48-49.

[33] M. Elwan, M. Attriss, A. Mahmoud, S. Salem, Characterization of rice straw ash and its use in clay bricks, Interceram, 57 (2008) 19-25.

[34] Development of eco-friendly porous fired clay bricks using pore-forming agents: A review, Journal of Environmental Management, J. Environ. Manage, 143 (2014) 186-196.

\section{Figure captions}

Fig. 1 The schematic drawing of the types of EDR cells used in the experiments. Anion exchange membrane $=$ AN; cation exchange membrane $=$ CAT .

Fig. 2 Development of voltage between the working electrodes (A), development of pH (B) and conductivity (C) of the ash suspensions within the first 14 days of EDR treatment. In this period of time the changes were considered significant.

Fig. 3 Distribution of elements in the electrodialytic cell after remediation. Anode end includes element at the anode, in the anion-exchange membrane and in the anolyte. Cathode end includes the element at the cathode, in the cation-exchange membrane and in the catholyte. Elements in the treated ash were measured on dry basis. Due to the bad mass balance of K resulting from pump leaking, the distribution of $\mathrm{K}$ in E3 was not given.

\section{Table captions}

Table 1 EDR conditions.

Table 2 Properties of the ashes studied (mean values and standard deviation of $\mathrm{N}$ replicates; $\mathrm{nd}=$ not determined). 
Table 3 Mass balances (\%) of each element in the experiments. The K value was not given in E3 due to the leaking problem with the circulating pipeline at the end of treatment, which especially had a great impact on the mass balance of $\mathrm{K}$, but a less impact on the other elements with relatively low concentrations.

Table 4 Overall results of treatment: $\mathrm{c}_{\mathrm{f}}$ for final concentration (mean values and standard deviation based on $\mathrm{N}$ measurements; na. = not analyzed).

Table 5 Leaching properties. 

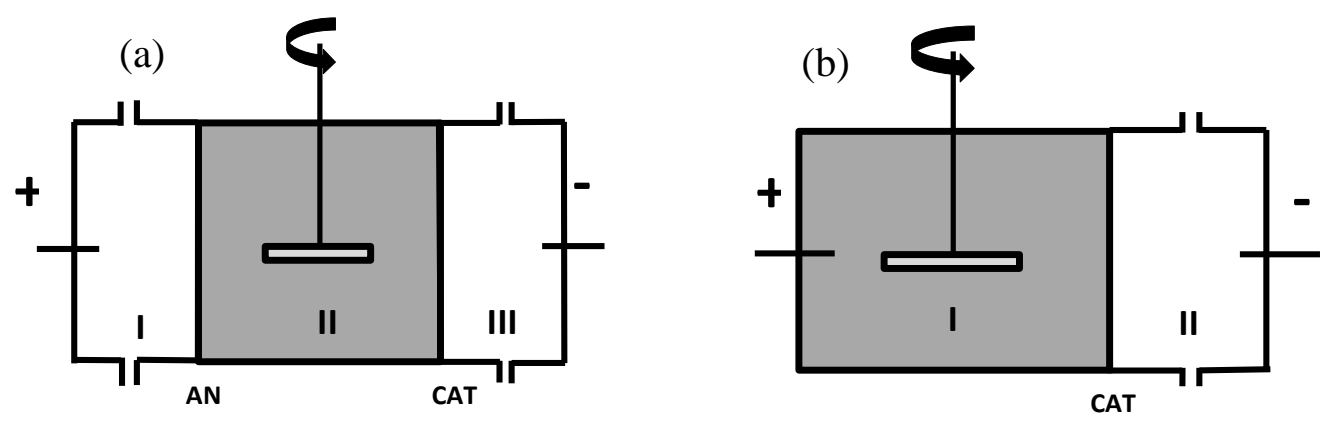

Figure 1 
(A)

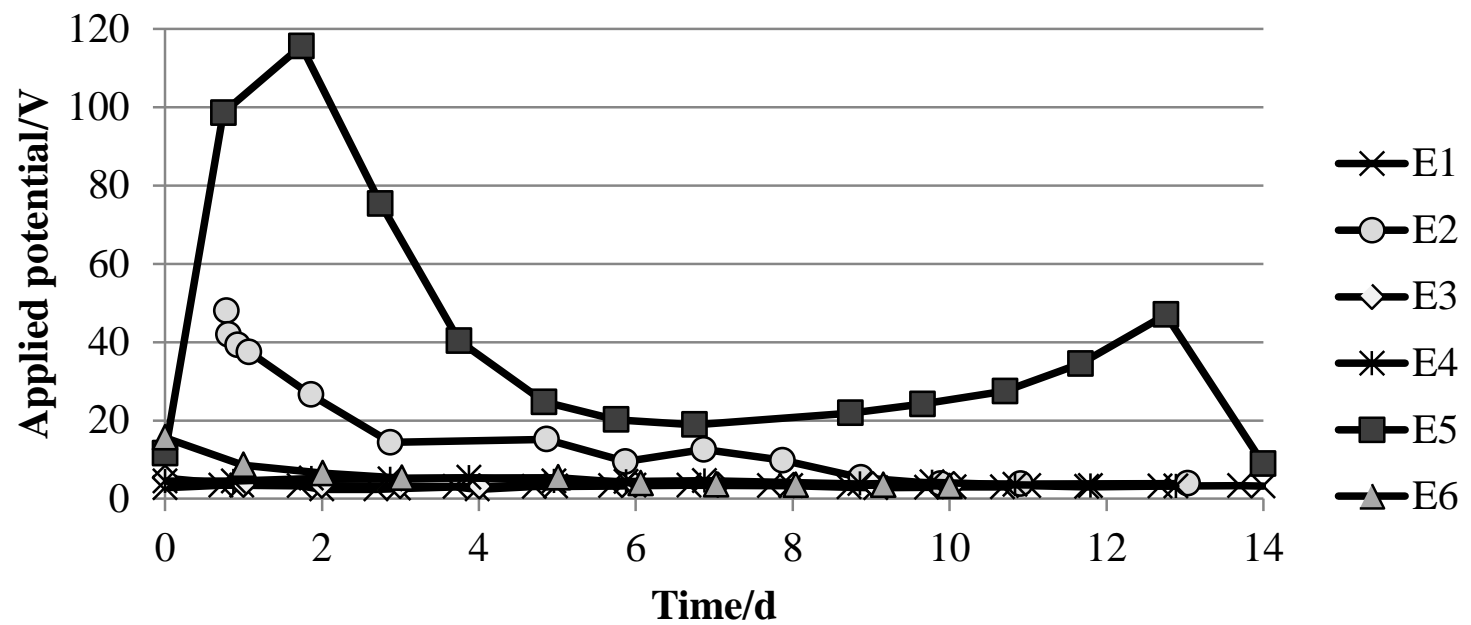

(B)

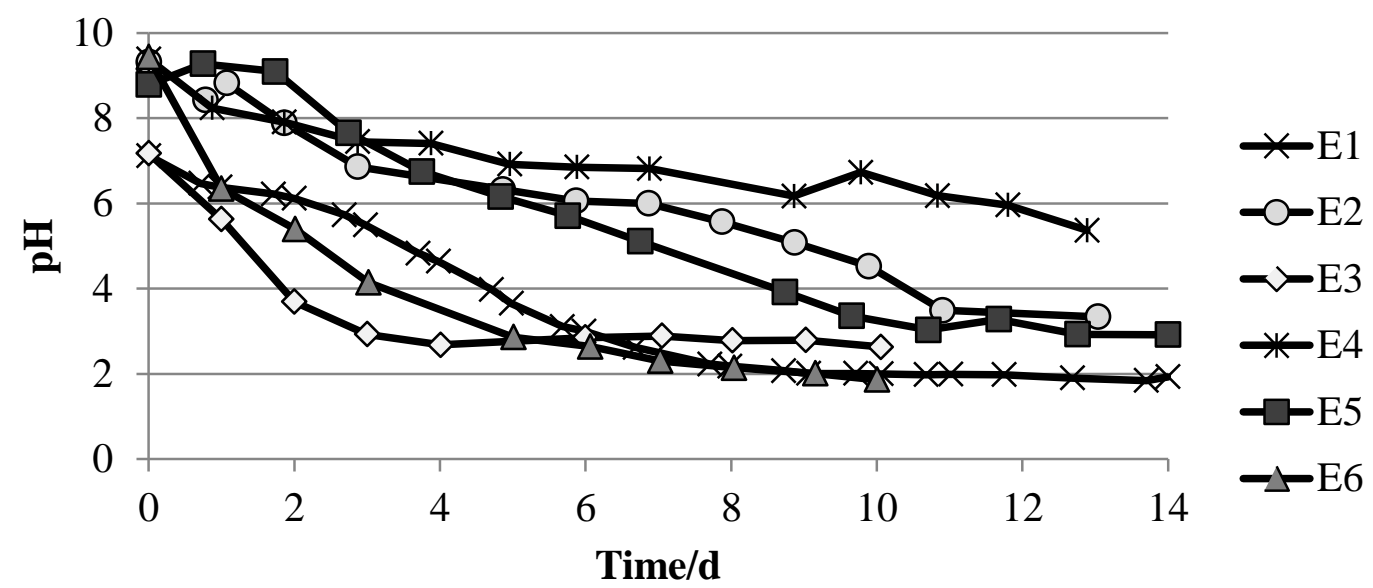

(C)

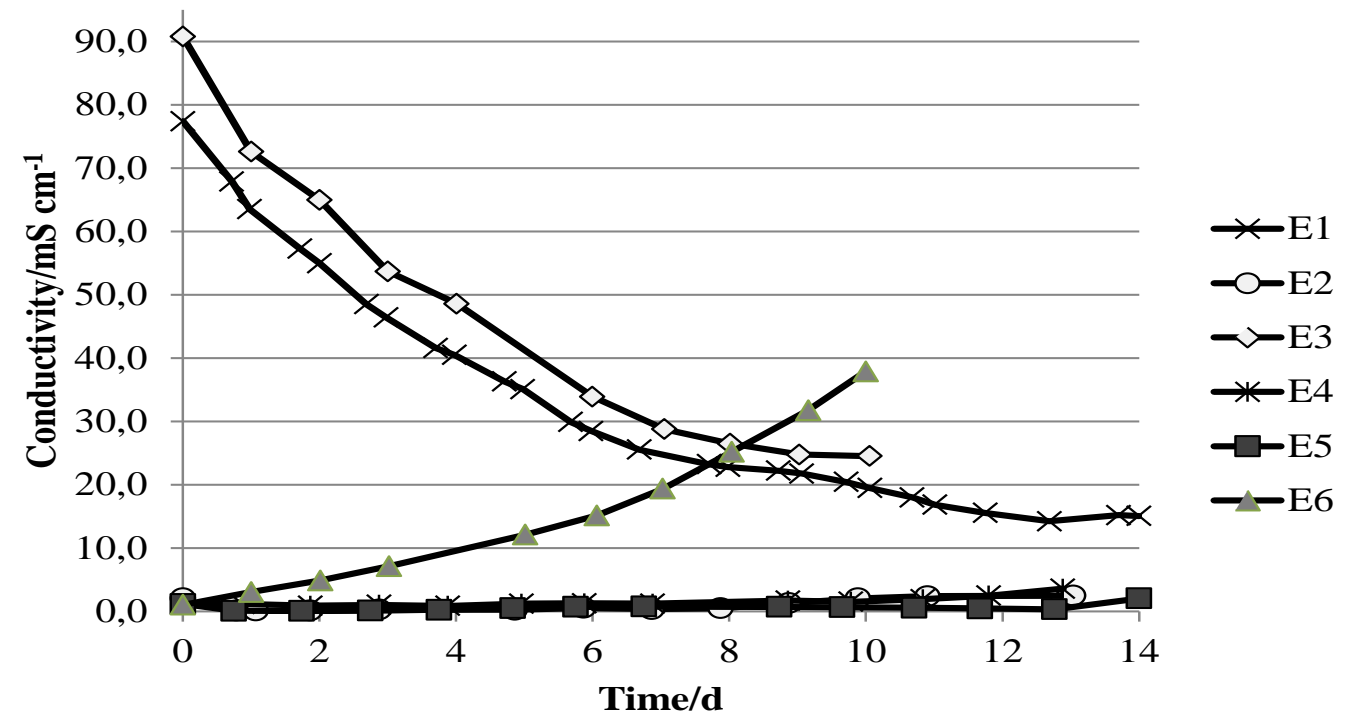

Figure 2 


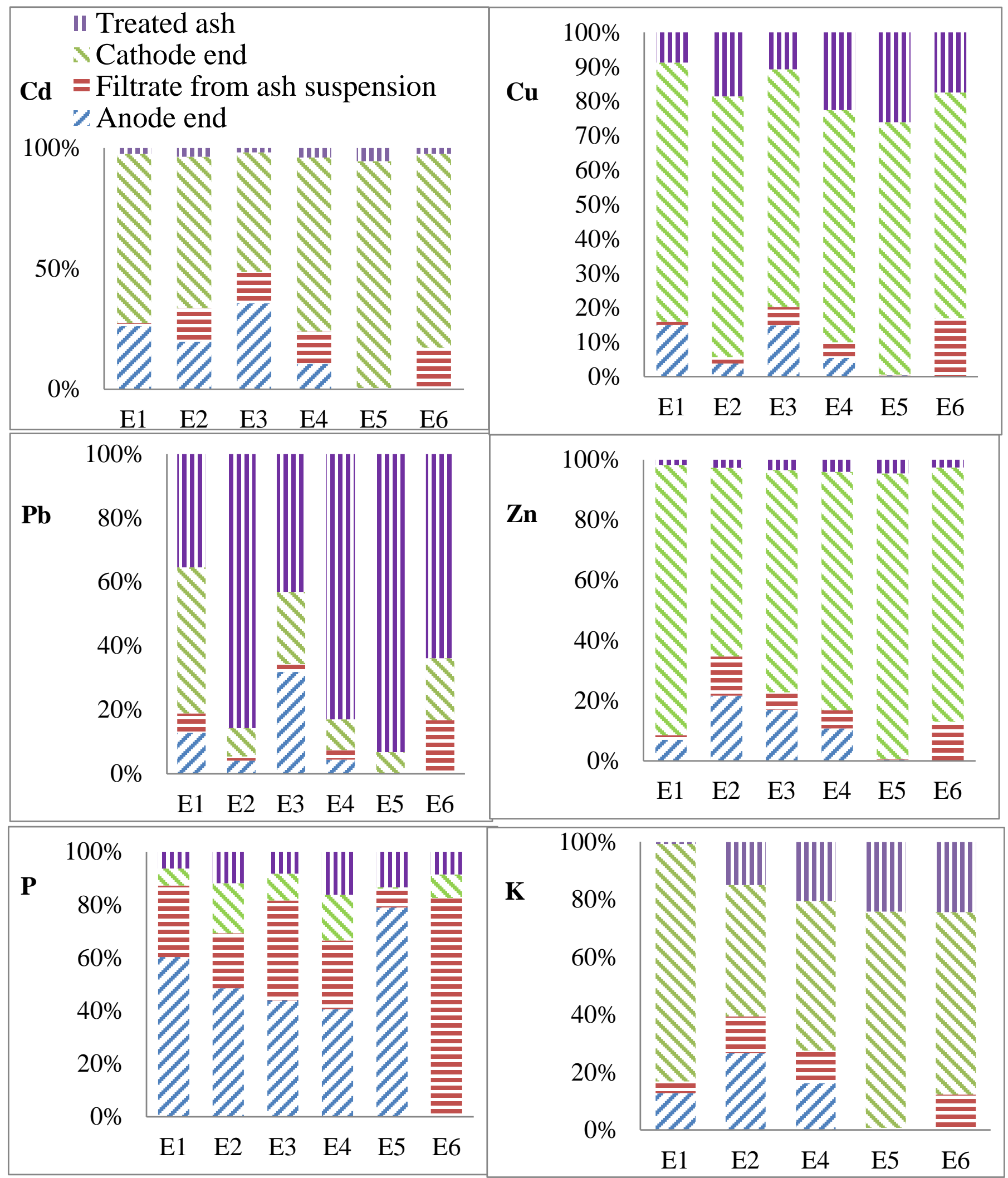

Figure 3 
Table 1 EDR conditions.

\begin{tabular}{cccccc}
\hline $\begin{array}{c}\text { Experiment } \\
\text { no. }\end{array}$ & Sample & Current/mA & Compartment & Duration/d & Charge/C \\
\hline E1 & EFA-1 & 50 & 3 & 14 & 60480 \\
E2 & WEFA-1 & 50 (Day 1) to 10 & 3 & $\sim 67$ & 60480 \\
E3 & EFA-2 & 50 & 3 & 10 & 43200 \\
E4 & WEFA-2 & 10 & 3 & 70 & 60480 \\
E5 & WEFA-2 & 40 & 3 & 10 & 34560 \\
E6 & WEFA-2 & 40 & 2 & 10 & 34560 \\
\hline
\end{tabular}


Table 2 Properties of the ashes studied (mean values and standard deviation of $\mathrm{N}$ replicates; nd = not determined).

\begin{tabular}{|c|c|c|c|c|c|c|c|c|}
\hline \multirow{2}{*}{\multicolumn{2}{|c|}{$\begin{array}{c}\text { Ash samples } \\
\text { Initial concentration } \\
\left(\mathrm{c}_{\mathrm{j}}\right)\end{array}$}} & \multirow{2}{*}{$\begin{array}{c}\text { EFA-1 } \\
\text { E1 } \\
(\mathrm{N}=5)\end{array}$} & \multirow{2}{*}{$\begin{array}{c}\text { WEFA-1 } \\
\text { E2 } \\
(\mathrm{N}=3)\end{array}$} & \multirow{2}{*}{$\begin{array}{c}\text { EFA-2 } \\
\text { E3 } \\
(\mathrm{N}=5)\end{array}$} & \multirow{2}{*}{$\begin{array}{c}\text { WEFA-2 } \\
\text { E4, E5, E6 } \\
(\mathrm{N}=4)\end{array}$} & \multirow{2}{*}{$\begin{array}{c}\text { Reference } \\
\text { Straw ash } \\
([5] /[7])\end{array}$} & \multirow{2}{*}{$\begin{array}{c}\text { Reference } \\
\text { Wood ash } \\
\text { [5] }\end{array}$} & \multirow{2}{*}{$\begin{array}{r}\text { Reference } \\
\text { Prewashed } \\
\text { straw ash [5] }\end{array}$} \\
\hline & & & & & & & & \\
\hline Major & $\mathrm{Ca}$ & $20.2 \pm 0.5$ & $105.0 \pm 0.2$ & $31.3 \pm 0.3$ & $122.3 \pm 1.1$ & $2.7 / 3.7$ & 113 & 12.1 \\
\hline element & $\mathrm{K}$ & $373.1 \pm 4.8$ & $40.2 \pm 0.4$ & $371.8 \pm 4.3$ & $35.7 \pm 0.3$ & 485/nd & 323 & 291 \\
\hline$\left(\mathrm{g} \mathrm{kg}^{-1} \mathrm{TS}\right)$ & $\mathrm{P}$ & $10.7 \pm 0.2$ & $44.7 \pm 0.1$ & $12.1 \pm 0.1$ & $48.0 \pm 0.5$ & nd & nd & nd \\
\hline \multirow{7}{*}{$\begin{array}{c}\text { Trace } \\
\text { element } \\
\text { (mg kg }{ }^{-1} \\
\text { TS) }\end{array}$} & As & $8.1 \pm 0.9$ & $24.4 \pm 0.2$ & $8.6 \pm 0.9$ & $17.1 \pm 0.8$ & nd & nd & nd \\
\hline & $\mathrm{Cd}$ & $9.0 \pm 0.2$ & $31.8 \pm 0.3$ & $9.3 \pm 0.2$ & $19.6 \pm 0.4$ & $18 / 11.3$ & 12.1 & 64 \\
\hline & $\mathrm{Cr}$ & $5.0 \pm 2.7$ & $17.7 \pm 0.4$ & $5.5 \pm 0.4$ & $19.1 \pm 0.5$ & nd/13.5 & nd & nd \\
\hline & $\mathrm{Cu}$ & $44.8 \pm 0.6$ & $253.6 \pm 1.4$ & $49.0 \pm 0.5$ & $186 \pm 3$ & $79 / 81$ & 303 & 370 \\
\hline & $\mathrm{Ni}$ & $1.0 \pm 0.2$ & $6.6 \pm 0.4$ & $3.0 \pm 0.6$ & $9.6 \pm 0.3$ & 15/nd & 77 & 35.3 \\
\hline & $\mathrm{Pb}$ & $27.2 \pm 0.9$ & $192.8 \pm 2.9$ & $35.0 \pm 0.4$ & $135 \pm 3$ & $93 / 17.3$ & 102 & 194 \\
\hline & $\mathrm{Zn}$ & $1013 \pm 14$ & $8008 \pm 67$ & $1089 \pm 10$ & $4960 \pm 36$ & 572/nd & 800 & 1271 \\
\hline \multirow{2}{*}{\multicolumn{2}{|c|}{$\begin{array}{l}\mathrm{pH}\left(\mathrm{H}_{2} \mathrm{O}\right) \\
\text { Conductivity } \\
\left(\mathrm{mS} \mathrm{cm}^{-1}\right)\end{array}$}} & $7.4 \pm 0.2$ & $9.4 \pm 0.0$ & $7.4 \pm 0.0$ & $9.9 \pm 0.0$ & $5.5\left(\mathrm{pH}_{\mathrm{KCl}}\right) / 5.9$ & $13.3\left(\mathrm{pH}_{\mathrm{KCl}}\right)$ & $5.7\left(\mathrm{pH}_{\mathrm{KCl}}\right)$ \\
\hline & & $98.1 \pm 0.8$ & $11.3 \pm 0.6$ & $109.5 \pm 2.8$ & $1.8 \pm 0.0$ & & & \\
\hline \multicolumn{2}{|c|}{ Water content (\%) } & 0.2 & 78.5 & 0.2 & 71.3 & $0.4 / 1.2$ & 0.4 & 87.5 \\
\hline \multicolumn{2}{|c|}{$\begin{array}{l}\text { Chloride content } \\
\text { (\%) }\end{array}$} & 23.9 & 0.1 & 22.7 & 0.1 & $20 / 21$ & 3.2 & 2.8 \\
\hline \multicolumn{2}{|l|}{ LOI (\%) } & $2.4 \pm 0.03$ & nd & $2.5 \pm 0.2$ & $7.3 \pm 0.3$ & 8.0/nd & 2.2 & 9.0 \\
\hline \multicolumn{2}{|c|}{$\begin{array}{l}\text { Ash recovery after } \\
\text { washing (\%) }\end{array}$} & & 17 & & 25 & & & \\
\hline \multicolumn{2}{|c|}{ Main minerals } & $\begin{array}{l}\mathrm{KCl}, \\
\mathrm{K}_{2} \mathrm{SO}_{4}\end{array}$ & $\begin{array}{l}\text { Quartz, } \\
\mathrm{CaCO}_{3}, \\
\mathrm{CaSO}_{4}\end{array}$ & & & & & \\
\hline
\end{tabular}


Table 3 Mass balances (\%) of each element in the experiments. The K value was not given in E3 due to the leaking problem with the circulating pipeline at the end of treatment, which especially had a great impact on the mass balance of $\mathrm{K}$, but a less impact on the other elements with relatively low concentrations.

\begin{tabular}{ccccccc}
\hline No. & $\mathrm{K}$ & $\mathrm{P}$ & $\mathrm{Cd}$ & $\mathrm{Cu}$ & $\mathrm{Pb}$ & $\mathrm{Zn}$ \\
\hline E1 & 94 & 99 & 91 & 124 & 94 & 110 \\
E2 & 108 & 89 & 102 & 114 & 96 & 92 \\
& & & & & & \\
E3 & - & 95 & 106 & 138 & 122 & 110 \\
E4 & 95 & 80 & 100 & 97 & 91 & 86 \\
& & & & & & \\
E5 & 102 & 82 & 105 & 102 & 94 & 94 \\
E6 & 87 & 78 & 93 & 105 & 83 & 92 \\
\hline
\end{tabular}


Table 4 Overall results of treatment: $\mathrm{c}_{\mathrm{f}}$ for final concentration (mean values and standard deviation based on $\mathrm{N}$ measurements; na. = not analyzed).

\begin{tabular}{|c|c|c|c|c|c|c|c|}
\hline \multicolumn{2}{|c|}{$\begin{array}{l}\text { Final concentration } c_{f} \text { in } \\
\text { experiments (parallel test } \\
N=3 \text { ) }\end{array}$} & $\begin{array}{c}\text { EFA-1 } \\
\text { E1 }\end{array}$ & $\begin{array}{c}\text { WEFA-1 } \\
\text { E2 }\end{array}$ & $\begin{array}{c}\text { EFA-2 } \\
\text { E3 }\end{array}$ & $\begin{array}{c}\text { WEFA-2 } \\
\text { E4 }\end{array}$ & $\begin{array}{c}\text { WEFA-2 } \\
\text { E5 }\end{array}$ & $\begin{array}{c}\text { WEFA-2 } \\
\text { E6 }\end{array}$ \\
\hline \multirow{3}{*}{$\begin{array}{l}\text { Major } \\
\text { element } \\
\left(\mathrm{g} \mathrm{kg}^{-1} \mathrm{TS}\right)\end{array}$} & $\mathrm{Ca}$ & $6.5 \pm 0.1$ & $8.4 \pm 0.1$ & $7.5 \pm 0.1$ & $9.3 \pm 0.2$ & $17.7 \pm 0.1$ & $7.6 \pm 0.1$ \\
\hline & $\mathrm{K}$ & $13.6 \pm 0.1$ & $8.7 \pm 0.2$ & $15.4 \pm 0.2$ & $9.6 \pm 0.2$ & $12.4 \pm 0.1$ & $10.7 \pm 0.2$ \\
\hline & $\mathrm{P}$ & $3.5 \pm 0.0$ & $6.3 \pm 0.1$ & $5.3 \pm 0.0$ & $8.6 \pm 0.2$ & $7.5 \pm 0.0$ & $4.5 \pm 0.1$ \\
\hline \multirow{7}{*}{$\begin{array}{l}\text { Trace element } \\
\left(\mathrm{mg} \mathrm{kg}^{-1} \mathrm{TS}\right)\end{array}$} & As & $1.6 \pm 2.2$ & $2.8 \pm 1.0$ & $1.8 \pm 2.5$ & $4.0 \pm 0.6$ & $2.0 \pm 0.5$ & $2.8 \pm 2.1$ \\
\hline & $\mathrm{Cd}$ & $1.06 \pm 0.03$ & $1.6 \pm 0.3$ & $0.99 \pm 0.03$ & $1.07 \pm 0.13$ & $1.6 \pm 0.1$ & $0.65 \pm 0.21$ \\
\hline & $\mathrm{Cr}$ & $21.3 \pm 0.6$ & $19.5 \pm 1.1$ & $22.1 \pm 0.4$ & $19.8 \pm 0.6$ & $19.6 \pm 0.4$ & $14.2 \pm 0.3$ \\
\hline & $\mathrm{Cu}$ & $25.7 \pm 0.2$ & $71.6 \pm 1.5$ & $39 \pm 1$ & $56 \pm 1$ & $70 \pm 1$ & $48 \pm 1$ \\
\hline & $\mathrm{Ni}$ & $3.6 \pm 0.4$ & $3.8 \pm 0.3$ & $9.4 \pm 0.3$ & $8.0 \pm 0.1$ & $7.7 \pm 0.2$ & $7.8 \pm 0.4$ \\
\hline & $\mathrm{Pb}$ & $47.8 \pm 0.7$ & $210.4 \pm 4.8$ & $100 \pm 1$ & $139 \pm 2$ & $168 \pm 1$ & $102 \pm 1$ \\
\hline & $\mathrm{Zn}$ & $100 \pm 1$ & $260 \pm 10$ & $224 \pm 2$ & $234 \pm 4$ & $300 \pm 4$ & $166 \pm 3$ \\
\hline \multirow{2}{*}{$\begin{array}{l}\mathrm{pH} \_a s h \\
\text { suspension }\end{array}$} & initial & 6.47 & 9.32 & 7.18 & 8.79 & 9.39 & 9.44 \\
\hline & final & 1.93 & 1.93 & 2.79 & 1.96 & 2.92 & 1.86 \\
\hline \multirow{2}{*}{\multicolumn{2}{|c|}{$\begin{array}{l}\text { Ash recovery (\%) } \\
\text { pH_ash after treatment }\end{array}$}} & 19 & 75 & 18 & 73 & 71 & 71 \\
\hline & & na. & na. & na. & 5.37 & 6.92 & 5.97 \\
\hline \multicolumn{2}{|c|}{ Energy consumption (Wh $\mathrm{g}^{-1}$ ) } & 1.03 & $\begin{array}{c}\text { Unstable } \\
\text { current }\end{array}$ & 0.84 & 1.02 & 8.42 & 1.06 \\
\hline \multicolumn{8}{|c|}{ Removal efficiency (\%) } \\
\hline \multicolumn{2}{|l|}{$\mathrm{Cd}$} & 98 & 96 & 98 & 96 & 94 & 98 \\
\hline \multicolumn{2}{|c|}{$\mathrm{Pb}$ (mass removed) } & 67 (0.91mg) & 18 (1.21mg) & 48 (0.83mg) & 25 (1.69mg) & 12 (0.82mg) & 47 (3.16mg) \\
\hline \multicolumn{2}{|l|}{$\mathrm{Cu}$} & 89 & 79 & 85 & 78 & 73 & 82 \\
\hline \multicolumn{2}{|l|}{$\mathrm{Zn}$} & 98 & 98 & 96 & 97 & 96 & 98 \\
\hline \multicolumn{2}{|l|}{ K } & 99 & 84 & 99 & 80 & 75 & 79 \\
\hline \multicolumn{2}{|l|}{$P$} & 94 & 89 & 92 & 87 & 89 & 93 \\
\hline
\end{tabular}


Table 5 Leaching properties.

\begin{tabular}{lcccccccccc}
\hline$\left(\boldsymbol{\mu} \mathbf{g ~ d m}^{-3}\right)$ & Se & $\mathrm{As}$ & $\mathrm{Ba}$ & $\mathrm{Cd}$ & $\mathrm{Cr}_{\text {tot }}$ & $\mathrm{Cu}$ & $\mathrm{Mn}$ & $\mathrm{Ni}$ & $\mathrm{Pb}$ & $\mathrm{Zn}$ \\
\hline Limiting value & 30 & 50 & 4000 & 40 & 500 & 2000 & 1000 & 70 & 100 & 1500 \\
Raw EFA-2 & 393 & 2321 & 131 & 2864 & 28 & 42 & 77 & 2.3 & $<2$ & 364 \\
Treated ash in E5 & $<2$ & 41 & 112 & $<2$ & 2 & $<2$ & 52 & 147 & $<2$ & 53 \\
Treated ash in E6 & 97 & 92 & 89 & 2 & 4.7 & $<2$ & 493 & 227 & $<2$ & 243 \\
\hline
\end{tabular}

